\title{
Utility of Prostatic Markers in the Differential Diagnosis of Adenocarcinomas Not Otherwise Specified from metastatic Tumours of the Oral Cavity
}

\author{
A. Epivatianos ${ }^{\mathrm{a}}$, A. Poulopoulos ${ }^{*}, \mathrm{a}$, A. Kiziridou ${ }^{\mathrm{b}}$, M. Belazi ${ }^{\mathrm{a}}$, S. Iordanidis ${ }^{\mathrm{c}}$, D. Antoniades ${ }^{\mathrm{a}}$ and \\ H. Zairi ${ }^{\mathrm{d}}$ \\ ${ }^{a}$ Department of Oral Medicine \& Pathology, School of Dentistry, Aristotle University of Thessaloniki, Thessaloniki \\ 54124, Greece \\ ${ }^{b}$ Department of Histopathology, Theagenion Anticancer Hospital of Thessaloniki, Thessaloniki, 54007, Greece \\ ${ }^{c}$ Department of Oral \& Maxillofacial Surgery, School of Dentistry, Aristotle University of Thessaloniki, Thessaloniki \\ 54124, Greece \\ ${ }^{d}$ Department of Histopathology, Interbalkan Hospital of Thessaloniki, 57001, Greece
}

\begin{abstract}
Objectives: The aim of the present study was to evaluate the expression of prostate-specific antigen (PSA), prostatic acid phosphatase (PAP) and [ alpha]- methylacyl-CoA racemase gene ( P504S) in normal salivary glands and adenocarcinomas not otherwise specified (NOS).

Material \& Methods: Tissue specimens of 18 normal salivary glands and 22 cases of adenocarcinomas NOS of the oral cavity, formalin-fixed, and paraffin-embedded were studied by using monoclonal antibodies for PSA, PAP and P504S.

Results: Positive staining for PSA was detected with one of the two used monoclonal antibodies in normal salivary glands (89\%) and adenocarcinomas NOS ( 45.45\%) whereas negative staining was observed for PAP and P504S.

Conclusions: Our results suggest that the detection of prostatic markers such as PAP, P504s with the use of monoclonal antibodies may offer an adjunctive aid in the differential diagnosis of adenocarcinomas NOS from metastatic carcinomas, when the origin of the primary tumours is unknown.
\end{abstract}

Keywords: Prostate-specific antigen (PSA), prostatic acid phosphatase (PAP), [alpha]-methylacyl-CoA racemase (AMACR gene), adenocarcinoma not otherwise specified (NOS), metastatic tumours.

\section{INTRODUCTION}

Prostate-specific antigen(PSA), a kallikrein-like serine protease (human kallikrein, hk3), is encoded by one of the three genes of the human kallikrein gene family mapped to long arms of chromosome 19 and therefore shares structural homology with tissue kallikrein (human kallikrein 1, hk1) and glandular kallikrein (human kallikrein 2, hk2) [1]. Prostatic acid phosphatase(PAP) is the prostatic isoenzyme of the widely distributed enzymatic acid phoshatase. Although PSA and PAP have become valuable markers for diagnosis of prostate carcinoma, their presence in a variety of normal, benign and malignant epithelial tissues [2] casts doubts about their specificity of their tissue expression. P504S, a prostate cancer specific gene, was recently discovered by using cDNA library subtraction with subsequent high throughput microarray screening of human prostate tissue. P504S, also referred to as AMACR gene, encodes [alpha]-methylacyl-coenzyme A racemase, a 382- amino acid protein involved in the beta-oxidation of branched-chain fatty acids. Although P504S was suggested as marker with specificity for prostate carcinoma its presence was documented in some normal tissues and carcinomas [3].

*Address correspondence to this author at the Department of Oral Medicine and Pathology, School of Dentistry, Aristotle University of Thessaloniki, 54006 Thessaloniki, Greece; Tel: +30 2310 999528; Fax: +30 2310 999455; E-mail:akpoul@yahoo.gr
Adenocarcinoma not otherwise specified (NOS), is a salivary gland carcinoma with ductal or glandular differentiation that does not resemble any known types of salivary gland carcinomas. It is uncommon and $60 \%$ of cases occur in major salivary glands with the parotid to be the most frequently involved [4].

The demonstration of PSA and PAP in normal salivary glands and neoplasm with the use of polyclonal and monoclonal antibodies is controversial [5-9]. Examination of P504S in adenocarcinoma NOS has not been reported in the literature.

The aim of the present study was to evaluate the expression of PSA, PAP and P504S in normal salivary glands and adenocarcinomas NOS, with the use of monoclonal antibodies in order to examine their possible utility in the differential diagnosis of primary oral adenocarcinomas NOS and metastatic tumours to the oral cavity.

\section{MATERIAL \& METHODS}

Twenty two cases of adenocarcinomas NOS, routinely processed, formalin-fixed, paraffin-embedded samples were retrieved from the files of diagnostic pathology of the Department of Oral Medicine and Oral Pathology and the Department of Histopathology of Theagenion Anticancer Hospital. Serial sections were cut and stained with hematoxylin and eosin and were reviewed for adequacy of tissue to study and for agreement with the original diagnosis by using estab- 
lished criteria [10]. Clinical features of all cases were recorded. The medical history of patients did not revealed any previous malignancy. Informed consent was obtained by all the patients, and the whole study was performed according to Helsinki II Declaration. Histologic grading of the tumours was performed according to previously described criteria [10]. Eighteen normal salivary glands (6 parotids, 6 submandibular glands and 6 labial) which were obtained from random biopsies or from non-neoplastic lesions were additionally used.

For the immunohistochemical detection of antigens, endogenous peroxidase was quenched with $3 \% \mathrm{H} 2 \mathrm{O} 2$ for 10 $\mathrm{min}$ at room temperature. Sections that intended for the detection of P504S were pretreated for antigen retrieval, whereas for the rest of the antibodies was ommited according to the recommendations of the product's company (Table 1). Then the sections were rinsed with phosphate buffer saline (PBS) and further blocking was performed by using normal goat serum at a 1:20 solution for $20 \mathrm{~min}$ at room temperature. After being washed with PBS the sections were incubated with monoclonal antibodies (Table 1). Tissue sections incubated for the same time with normal goat serum were used as negative controls and sections from a prostate carcinoma as positive controls. The procedures were performed using a TechMate 1000 (Ventana Med Systems, Tuscon, AZ, USA) automated immunostainer. The avidinbiotin-complex method was performed for the detection of PSA and PAP with the primary antibody supplied from Biogenex (San Ramon, CA, USA) and streptavidin-biotincomplex method for the detection of PSA and P504S with the primary antibodies supplied from Novocastra ( Newcastle upon Tyne, UK) and Biocare (Carmino Diablo, CA, USA) respectively. The reaction was developed using diaminobenzidine and hematoxylin was used as counterstain. Owing to the high level of endogenous biotin, especially in striated and excretory ductal cells, a biotin blocking system (XO590 DakoCytomation, Glostrup, Denmark) was applied to both immunohistochemical methods. The staining intensity was assessed as weak, moderate and strong and the pattern of immunostaining as focal, multifocal and diffuse. Sections were examined by two of the authors (E.A and K.A) independently of each other. The slides then were reviewed by the examiners as a group and discussion was occasionally necessary to establish uniformity.

\section{RESULTS}

Normal salivary glands and adenocarcinoma NOS expressed PSA with the use of one monoclonal antibody (Biogenex) but not with the other (Novocastra). Positive immunostaining for PSA was found in 16/18 (89\%) of cases of normal salivary glands ( $6 / 6$ parotids, $6 / 6$ submandibular and $4 / 6$ labial glands) in 8 males and 8 females. The cells of striated and excretory ducts of parotid and submandibular glands expressed PSA with strong intensity whereas acini and intercalated ducts were negative (Fig. 1). In normal labial salivary glands the intralobular ductal cells expressed PSA with strong intensity whereas acinar cells were negative (Fig. 2). In 2 cases of adenocarcinomas NOS which were PSA positive, the adjacent normal minor salivary glands showed results similar to labial glands.

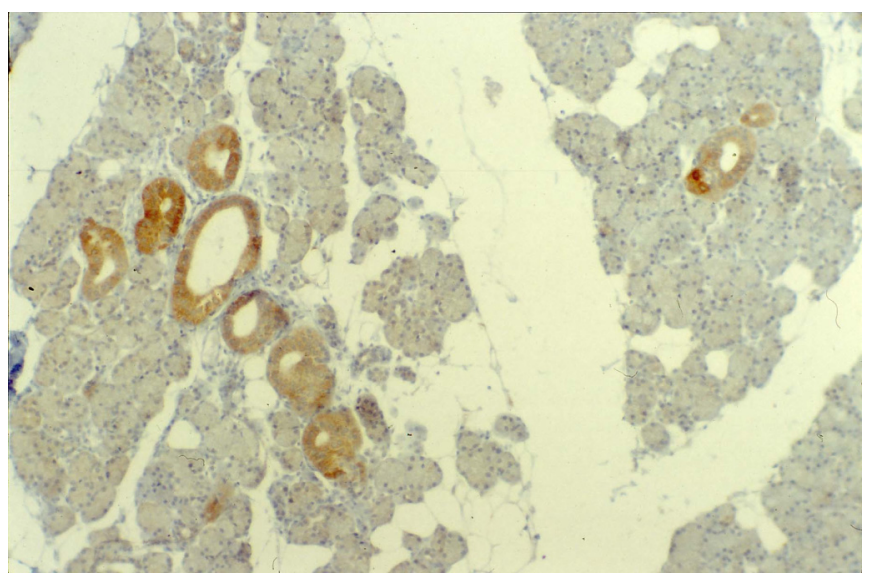

Fig. (1). Normal parotid gland. Strong expression of prostate- specific antigen in the cells of striated and excretory ducts. (AvidinBiotin-Complex method. Original magnification X 33).

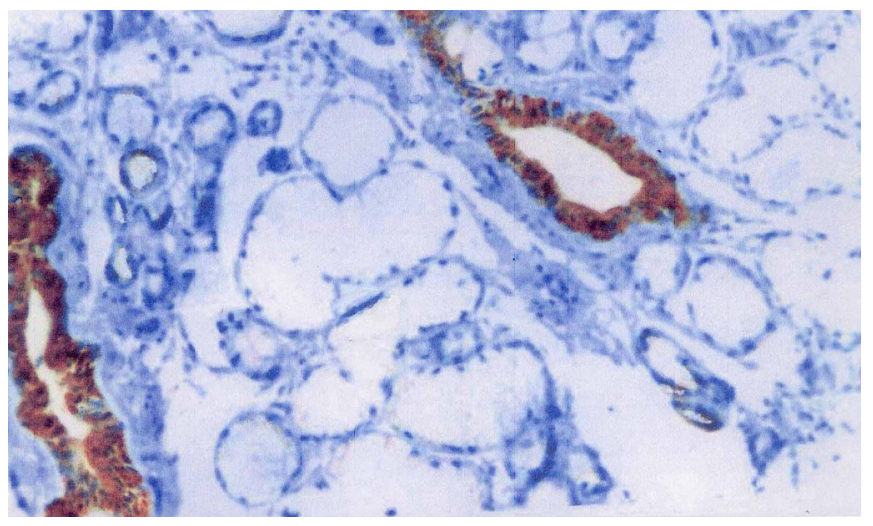

Fig. (2). Normal labial salivary glands. The cells of excretory ducts are strongly immunoreactive for prostate specific antigen. (AvidinBiotin-Complex method. Original magnification X 66).

The clinical features, histologic grade and immunostaining for PSA in adenocarcinomas NOS, are summarized in Table 2. The age of patients ranged from 28 to 80 years with an average value 59.8 years. The tumour most often $(54.5 \%)$

Table 1. Clone, Source and Pretreatment for Antigen Retrieval, Dilutions and Incubation Time of Primary Antibodies

\begin{tabular}{|c|c|c|c|c|c|}
\hline Antibody & Source & Clone & Pretreatment & Dilution & Incubation \\
\hline PSA & Biogenex, San Ramon, CA, USA & Er-Pr-8 & No & $1: 80$ & $30 \mathrm{~min}$ \\
\hline PAP & Biogenex, San Ramon, CA, USA & BGX013A & No & $1: 150$ & $30 \mathrm{~min}$ \\
\hline P504S & Biocare Med. Carmino Diablo, CA, USA & P504S & Microwave; citrate buffer $0.01 \mathrm{M} ; \mathrm{pH} 7,95^{\circ} \mathrm{C} ; 15 \mathrm{~min}$ & Prediluted & $30 \mathrm{~min}$ \\
\hline
\end{tabular}


Table 2. Clinical Features, Histologic Grade and Immunostaining of Prostate-Specific Antigen (PSA) in Adenocarcinomas NOS

\begin{tabular}{|c|c|c|c|c|c|c|}
\hline Case & Gender & Age & Location & Histologic Grade & Immunostaining Pattern & Intensity of Staining \\
\hline 1 & $\mathrm{~F}$ & 64 & Palate & II & Diffuse & Moderate \\
\hline 2 & $\mathrm{~F}$ & 28 & Buccal mucosa & I & Multifocal & Moderate \\
\hline 3 & M & 63 & Labial mucosa & II & Negative & - \\
\hline 4 & M & 74 & Labial mucosa & II & Focal & Weak \\
\hline 5 & $\mathrm{~F}$ & 50 & Palate & I & Negative & - \\
\hline 6 & $\mathrm{~F}$ & 64 & Palate & I & Negative & - \\
\hline 7 & $\mathrm{~F}$ & 55 & Buccal mucosa & I & Negative & - \\
\hline 8 & M & 65 & Palate & II & Negative & - \\
\hline 9 & $\mathrm{~F}$ & 39 & Buccal mucosa & I & Diffuse & Weak \\
\hline 10 & M & 63 & Palate & I & Negative & - \\
\hline 11 & M & 65 & Palate & I & Diffuse & Moderate \\
\hline 12 & $\mathrm{~F}$ & 49 & Buccal mucosa & I & Negative & - \\
\hline 13 & $\mathrm{~F}$ & 51 & Buccal mucosa & I & Multifocal & Moderate \\
\hline 14 & $\mathrm{~F}$ & 64 & Palate & I & Negative & - \\
\hline 15 & $\mathrm{~F}$ & 56 & Buccal mucosa & I & Diffuse & Weak \\
\hline 16 & M & 68 & Palate & II & Negative & - \\
\hline 17 & M & 80 & Palate & II & Negative & - \\
\hline 18 & $\mathrm{~F}$ & 67 & Palate & I & Diffuse & Moderate \\
\hline 19 & $\mathrm{~F}$ & 63 & Palate & I & Negative & - \\
\hline 20 & M & 66 & Palate & I & Diffuse & Moderate \\
\hline 21 & $\mathrm{~F}$ & 57 & Palate & I & Negative & - \\
\hline 22 & M & 65 & Labial Mucosa & II & Focal & Weak \\
\hline
\end{tabular}

occurred in the $6^{\text {th }}$ decade of life and located in palate $(59 \%)$. Histologically $68 \%$ of cases were low-grade (grade I) and $32 \%$ intermediate grade (grade II) (Fig. 3). Expression of PSA was observed in 10/22 (45.45\%) of cases independently of patient's sex and histologic grade. The staining intensity ranged from weak to moderate (Fig. 4).

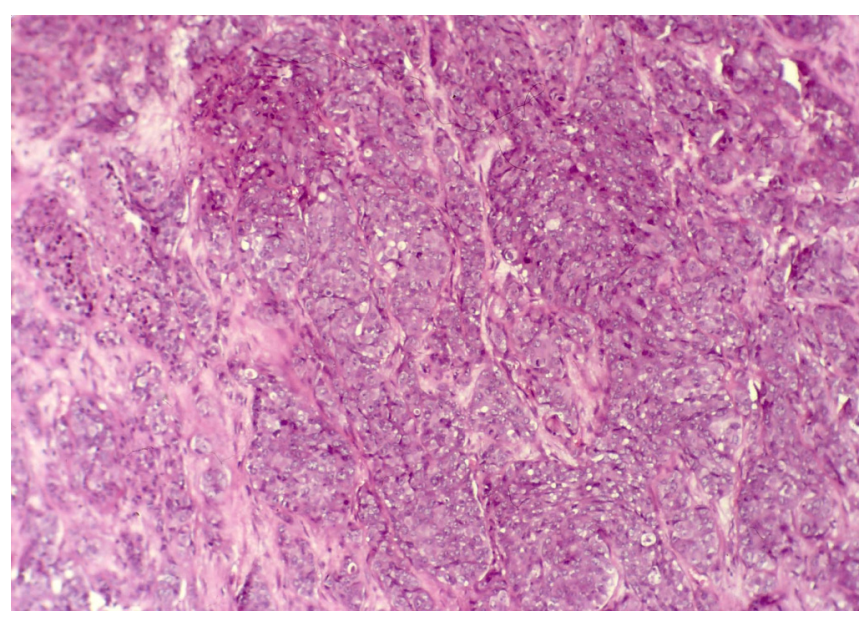

Fig. (3). Low grade (I) adenocarcinoma, not otherwise specified. Glandular and ductal structures. (Hematoxylin and eosin. Original magnification X 33).
Normal salivary glands and adenocarcinomas NOS did not expressed PAP and P504S.

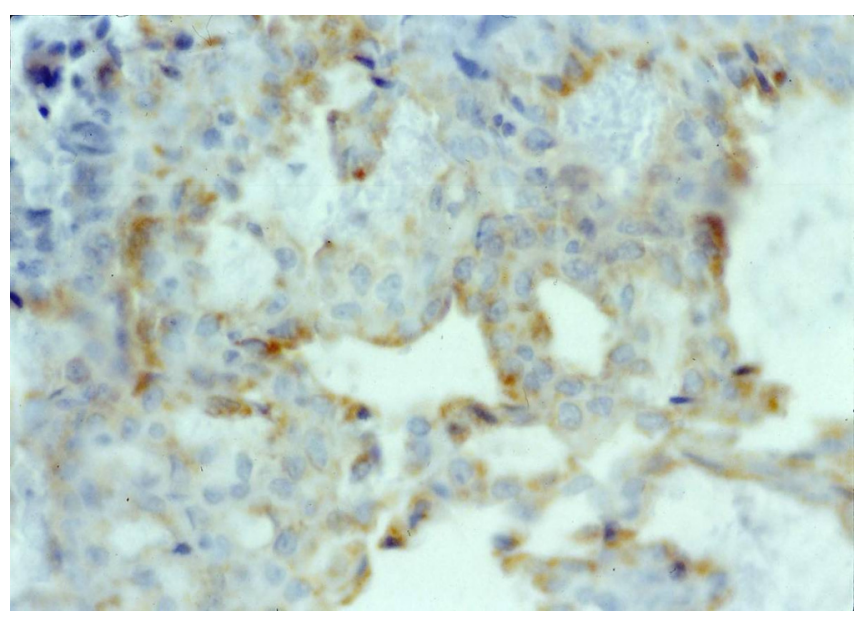

Fig. (4). Adenocarcinoma, not otherwise specified. Diffuse expression of prostate specific antigen. Moderate staining intensity of luminal and non-luminal tumor cells in ductal-like structures. (Avidin-Biotin-Complex method. Original magnification X 132).

\section{DISCUSSION}

Comparison of our results in normal salivary glands and immunohistochemical procedures with previous reports are 
presented in Table 3. Our results for PSA in parotid gland are in concordance with previous studies where polyclonal $[5,7,9]$ and monoclonal antibodies $[6,8]$ were used. On the contrary to our results in the studies of Fan et al. [8] and Tazawa et al. [9] expression of PSA was not demonstrated by using monoclonal antibodies. Our results in the submandibular gland agree with previous study [6] where the expression of PSA was detected by using two monoclonal antibodies. Also partial agreement exists with the study of Tazawa et al.
[9] where the expression of PSA was reported by using a polyclonal antibody but not by a monoclonal one. As concern our results in minor salivary glands discrepancy exists with the study of Tazawa et al. [9] where polyclonal and monoclonal antibodies failed to demonstrate the expression of PSA.

As concern the presence of PAP, the results of the current study agree with the reports of Van Krieken [5] and Tazawa

Table 3. Comparative Profile of Present Study and Previous Reports in Normal Salivary Glands

\begin{tabular}{|c|c|c|c|c|c|}
\hline Authors & Anatomic Location Immunostaining & Source & $\begin{array}{l}\text { Type of } \\
\text { Antibody }\end{array}$ & Dilution & $\begin{array}{c}\text { Antigen } \\
\text { Retrieval }\end{array}$ \\
\hline \multirow[t]{2}{*}{$\begin{array}{c}\text { Van Krieken } \\
{[5]}\end{array}$} & $\begin{array}{l}\text { Parotid } \\
\text { Positive }\end{array}$ & Dakopatts, Glostrup, Denmark & $\begin{array}{c}\text { Polyclonal } \\
\text { PSA }\end{array}$ & 1: 200 & NO \\
\hline & $\begin{array}{c}\text { Parotid } \\
\text { Negative }\end{array}$ & Dakopatts, Glostrup, Denmark & $\begin{array}{c}\text { Polyclonal } \\
\text { PAP }\end{array}$ & 1: 300 & NO \\
\hline \multirow[t]{3}{*}{$\begin{array}{c}\text { Elgamal et al. } \\
{[6]}\end{array}$} & $\begin{array}{c}\text { Parotid } \\
\text { Submandibular } \\
\text { Positive }\end{array}$ & Dako Carpinteria, CA, USA & $\begin{array}{c}\text { Monoclonal } \\
\text { PSA }\end{array}$ & $1: 20$ & NO \\
\hline & $\begin{array}{c}\text { Parotid } \\
\text { Submandibular } \\
\text { Positive }\end{array}$ & Zymed, Laboratories, CA, USA & $\begin{array}{l}\text { Monoclonal } \\
\text { PSA }\end{array}$ & $1: 25$ & NO \\
\hline & $\begin{array}{c}\text { Parotid } \\
\text { Submandibular } \\
\text { Positive }\end{array}$ & Dako Carpinteria, CA, USA & $\begin{array}{c}\text { Monoclonal } \\
\text { PAP }\end{array}$ & $1: 50$ & $\mathrm{NO}$ \\
\hline \multirow[t]{4}{*}{$\begin{array}{c}\text { Alanen et al. } \\
{[7]}\end{array}$} & $\begin{array}{c}\text { Parotid } \\
\text { Negative }\end{array}$ & Biogenex, San Ramon, CA, USA & $\begin{array}{c}\text { Monoclonal } \\
\text { PSA }\end{array}$ & $1: 10$ & NO \\
\hline & $\begin{array}{l}\text { Parotid } \\
\text { Positive }\end{array}$ & Biogenex, San Ramon, CA, USA & $\begin{array}{c}\text { Polyclonal } \\
\text { PSA }\end{array}$ & $1: 10$ & $\mathrm{NO}$ \\
\hline & $\begin{array}{l}\text { Parotid } \\
\text { Positive }\end{array}$ & Dakopatts, Glostrup, Denmark & $\begin{array}{c}\text { Monoclonal } \\
\text { PSA }\end{array}$ & $1: 1000$ & $\begin{array}{c}\text { Microwave } \\
\text { processing }\end{array}$ \\
\hline & $\begin{array}{l}\text { Parotid } \\
\text { Positive }\end{array}$ & Dakopatts, Glostrup, Denmark & $\begin{array}{c}\text { Polyclonal } \\
\text { PSA }\end{array}$ & $1: 1000$ & $\begin{array}{l}\text { Pepsin } \\
\text { Pretreat- } \\
\text { ment }\end{array}$ \\
\hline \multirow[t]{2}{*}{ Fan et al. [8] } & $\begin{array}{c}\text { Parotid } \\
\text { Negative }\end{array}$ & Signet & $\begin{array}{c}\text { Monoclonal } \\
\text { PSA }\end{array}$ & 1: 100 & NO \\
\hline & $\begin{array}{l}\text { Parotid } \\
\text { Positive }\end{array}$ & Dako & $\begin{array}{c}\text { Monoclonal } \\
\text { PAP }\end{array}$ & Prediluted & NO \\
\hline \multirow[t]{3}{*}{$\begin{array}{c}\text { Tazawa et al. } \\
{[9]}\end{array}$} & $\begin{array}{c}\text { Parotid } \\
\text { Submandibular } \\
\text { Positive } \\
\text { Minor } \\
\text { Negative } \\
\end{array}$ & Dako Kyoto, Japan & $\begin{array}{c}\text { Polyclonal } \\
\text { PSA }\end{array}$ & 1: 100 & NO \\
\hline & $\begin{array}{c}\text { Parotid } \\
\text { Submandibular } \\
\text { Minor } \\
\text { Negative }\end{array}$ & Dako Kyoto, Japan & $\begin{array}{c}\text { Monoclonal } \\
\text { PSA }\end{array}$ & $1: 20$ & $\begin{array}{l}\text { Microwave } \\
\text { processing }\end{array}$ \\
\hline & $\begin{array}{c}\text { Parotid } \\
\text { Submandibular } \\
\text { Minor } \\
\text { Negative }\end{array}$ & Dako Kyoto, Japan & $\begin{array}{c}\text { Monoclonal } \\
\text { PAP }\end{array}$ & $1: 400$ & $\begin{array}{c}\text { Microwave } \\
\text { processing }\end{array}$ \\
\hline \multirow[t]{3}{*}{ Present study } & $\begin{array}{c}\text { Parotid } \\
\text { Submandibular } \\
\text { Labial } \\
\text { Positive }\end{array}$ & Biogenex, San Ramon, CA, USA & $\begin{array}{c}\text { Monoclonal } \\
\text { PSA }\end{array}$ & $1: 80$ & $\mathrm{NO}$ \\
\hline & $\begin{array}{c}\text { Parotid } \\
\text { Submandibular } \\
\text { Labial } \\
\text { Negative }\end{array}$ & Novocastra, Newcastle upon Tyne, UK & $\begin{array}{l}\text { Monoclonal } \\
\text { PSA }\end{array}$ & $1: 30$ & NO \\
\hline & $\begin{array}{c}\text { Parotid } \\
\text { Submandibular } \\
\text { Labial } \\
\text { Negative }\end{array}$ & Biogenex, San Ramon, CA, USA & $\begin{array}{c}\text { Monoclonal } \\
\text { PAP }\end{array}$ & $1: 150$ & NO \\
\hline
\end{tabular}


et al. [9] where polyclonal and monoclonal antibodies were used respectively. On the contrary Elgamal et al. [6] and Fan et al. [8] detected expression of PAP with the use of monoclonal antibody.

In the present study we used monoclonal antibody for the detection of PSA on purpose to minimize cross-reactivity with human kallikrein 1 and 2 although theoretically crossreactivity cannot be excluded. Also we used monoclonal antibody for the detection of PAP because the specificity of monoclonal antibodies is better than that of polyclonal antibodies [11]. The discrepancies of our results for PSA with the study of Fan et al. [8] and Tazawa et al. [9] as well as for PAP with those of Elgamal et al. [6] and Fan et al. [8], where monoclonal antibodies were used, may be due to different immunohistochemical procedures (Table 3). The limits of an immunohistochemical assay vary upon factors such as antigen retrieval procedure, the concentration of primary and secondary antibodies, the length of incubation with such antibodies and the sensitivity of enzymatic reaction. However, in the current study the expression of PSA in normal minor salivary glands was demonstrated and according to our knowledge a similar result has not previously reported in the literature.

In the present study expression of PSA was demonstrated in both sexes and this result is in accordance with the study of Elgamal et al. [6] where monoclonal antibodies were used. It has been suggested that PSA is expressed from salivary gland tumours in androgen dependent manner [1] and its presence in women is likely due to steroid hormones such as progestin or glycocorticoid that could derepress the gene in cells with the appropriate receptors [12]. The function of PSA in salivary glands is not clear. It has been proposed that may be involved in regulating insulin-like growth factor binding proteins 2 and 3 and insulin-like growth factor 1 [13].

The results of the present study showed positive expression for PSA $(45.45 \%)$ in adenocarcinomas NOS, independently of the patient's sex and are similar to the study of Tazawa et al. [9] where positive results (41\%) were found in both sexes with the use of polyclonal antibody but not with monoclonal one. Also they are similar to the results of Van Krieken [5] with the use of polyclonal antibody. Conclusively from the present and previous studies it seems that PSA may be demonstrated in adenocarcinomas NOS, with the use of both monoclonal and polyclonal antibodies whereas PAP only with polyclonal ones. In the current study the results for PSA confirm the existing doubts about the specificity of its tissue expression.

Metastatic adenocarcinomas occasionally simulate primary malignant neoplasms in major salivary glands and oral cavity and may present difficulties in separation from adenocarcinomas NOS, because of their relatively nonspecific histologic appearance [10]. Breast and lung carcinomas commonly metastasize in the oral cavity [14] whereas colorectal [15], hepatic [16], gastric [17, 18] and prostate carcinomas [19] are rare. Among these carcinomas, PSA expression has been demonstrated in breast [20-22] and lung carcinomas [23] with the use of polyclonal antibodies. Therefore pathologists in case of surgical material originating from males should use with caution polyclonal antibodies for the detection of PSA as an adjunctive aid for the differential diagnosis between primary adenocarcinomas NOS, from metastatic lung and prostate carcinomas when the origin of the primary tumours is unknown. With regard to PAP, its expression has commonly been demonstrated in rectal carcinoid tumours [2] and prostate carcinoma [24] with the use of monoclonal antibody whereas its absence in adenocarcinomas NOS, was demonstrated in the current study and the report of Tazawa et al. [9]. These findings allow us to suggest that the detection of PAP with the use of monoclonal antibodies may offer an adjunctive aid in the differential diagnosis of metastatic rectal carcinoid tumours and prostate carcinoma from primary adenocarcinomas NOS.

In the current study P504S expression was not found in adenocarcinoma NOS whereas in prostate, hepatic and colorectal carcinomas its expression was reported in $92 \%, 81 \%$ and $80 \%$ of cases respectively [25]. Therefore the use of P504S may offer an adjunctive aid in the differential diagnosis of primary adenocarcinoma NOS from metastatic prostate, hepatic and colorectal carcinomas when the origin of the primary tumours is unknown.

In conclusion our results suggest that the immunohistochemical detection of PAP and P504s with the use of monoclonal antibodies, may offer an adjunctive aid in the differential diagnosis of primary oral adenocarcinomas NOS from metastatic carcinomas to the oral cavity, when the origin of the primary tumours is unknown.

\section{REFERENCES}

[1] Diamantis E. New diagnostic applications and physiological functions of prostate specific antigen. Scand J Clin Lab Invest 1995; 55 : 105-12.

[2] Azumi N, Traweek S, Battifora M. Prostatic acid phospatase in carcinoid tumors. Immunohistochemical and immunoblot studies. Am J Surg Pathol 1992; 16: 526-27.

[3] Nassar A, Amin MB, Sexton DG, Cohen C. Utility of alphamethylacyl coenzyme A racemase ( P504S antibody) as a diagnostic immunohistochemical marker for cancer. Appl Immunohistochem Mol Morphol 2005; 13: 252-55.

[4] Ellis GL, Auclair PL. Atlas of Tumor Pathology: Tumors of the Salivary Glands. Washington, DC:Armed Forces Institute of Pathology; 1996; p. 155-373.

[5] Van Krieken JM. Prostate marker immunoreactivity in salivary gland neoplasms : a rare pitfall in immunohistochemistry. Am J Surg Pathol 1993; 17: 410-14.

[6] Elgamal AA, Ectros NL, Sunardhi-Widyaputa S, Van Poppel HP, Van Damme BJ, Baert LV. Detection of prostate specific antigen in pancreas and salivary glands : a potential impact on prostate cancer overestimation. J Urol 1996; 156: 464-68.

[7] Alanen K, Kuopio T, Koskinen P, Nevalainen T. Immunohistochemical labelling for prostate- specific antigen in non-prostatic tissues. Pathol Res Pract 1996; 192: 223-27.

[8] Fan CY, Wang J, Barnes EL. Expression of androgen receptor and prostatic specific markers in salivary duct carcinoma: an immunohistochemical analysis of 13 cases and review of the literature. Am J Surg Pathol 2000; 24: 579-86.

[9] Tazawa K, Kurihara Y, Kamodhida S, Tsukada K, Tsutsumi Y. Localization of prostate-specific antigen-like immunoreactivity in human salivary gland and salivary gland tumors. Pathol Inter 1999; 49: 500-05.

[10] Auclair PL, Ellis GL. Adenocarcinoma, not otherwise specified. In: Ellis GL, Auclair Pl, Gnepp DG editors. Pathology of Salivary Glands. Philadelphia : W.B. Saunders, 1991, p. 318-332.

[11] Lam K, Li C, Yam L, Sun T, Lee G, Ziesmer S. Improved immunohistochemical detection of prostatic specific phosphatase by a monoclonal antibody. Prostate 1989; 15: 13-21.

[12] Monne M, Croce C, Yu H, Diamantis E. Molecular characterization of prostate-specific antigen messenger RNA expressed in breast tumors. Cancer Res 1994; 54: 6344-47. 
[13] Kanety H, Madjar Y, Dagan Y, et al. Serum insulin-like growth factor-binding protein-2 (IGFBP-2) is increased and IGFBP-3 is decreased in patients with prostate cancer: correlation with serum prostate-specific antigen. J Clin Endocr Metab 1993; 77: 229-33.

[14] Guimaraes A, Perdigao P, Siqueira F, Castro W, Gomez R. Oral metastasis of breast carcinoma diagnosed by fine needle aspiration cytology. A case report. Acta Cytol 2003; 47: 1074-76.

[15] Rusthoven J, Fine S, Thomas G. Adenocarcinoma of the rectum metastatic to the oral cavity. Two cases and review of the literature. Cancer 1984; 54: 1110-12.

[16] Pires F, Sagara R, Correa M, Pereira C, Vargas P, Lopes M. Oral metastasis of a hepatocellular carcinoma. Oral Surg Oral Med Oral Pathol Oral Radiol Endod 2004; 97: 359-68.

[17] Owa A, Gallimore A, Ajulo S, Cheesman A. Metastatic adenocarcinoma of ethmoids in a patient with previous gastric adenocarcinoma : a case report. J Laryngol Otol 1995; 109: 759-61.

[18] Gallo A, Pescarmona E, Crupi J, Corsetti G, De Vincentis M. Bilateral tonsilar metastasis of gastric adenocarcinoma. Head Neck 1992; 14: 55-57.
[19] Piattelli A, Fioroni M, Rubini C. Gingival metastasis from a prostatic adenocarcinoma : report of a case. J Periodontol 1999; 70: 441-44.

[20] Yao GY, Zhou JL, Zhao ZS, Ruan J. Biological characteristics of breast carcinoma with neuroendocrine cell differentiation. Chin Med J 2004; 117: 1536-40.

[21] Yu H, Giai M, Diamantis E, et al. Prostate-specific antigen is a new favorable indicator for women with breast cancer. Cancer Res 1995; 55: 2104-10.

[22] Alanen K, Kuopio T, Collon Y, Kranqvist P, Juntti L, Nevalainen $\mathrm{T}$. Immunohistochemical labelling for prostate-specific antigen in beast carcinomas. Breast Cancer Res Treat 1999; 56: 169-76.

[23] May E, Perentes E. Anti-Leu 7 immunoreactivity with human tumours: its value in the diagnosis of prostate carcinoma. Histopathology 1987; 11: 295-04.

[24] Torenberek R, Lagendijl JH, Van Diest PJ, Bril H, Van de Molengraft FJ, Meijer JL. Value of a panel to identify the primary origin of adenocarcinoma. Histopathology 1998: 32: 20-27.

[25] Jiang Z, Woda BA, Dresser K, Fanger G, Xu J, Rock KL. Expression of P504S in variant malignant neoplasms and normal tissues: A study of 715 cases. (abstract) Mod Pathol 2002; 15: 306. 